\title{
Endothelial cell-specific aryl hydrocarbon receptor knockout mice exhibit hypotension mediated, in part, by an attenuated angiotensin II responsiveness
}

\author{
Larry N. Agbora, Khalid M. Elased ${ }^{\mathrm{b}}$, and Mary K. Walkera, \\ ${ }^{a}$ Department of Pharmaceutical Sciences, College of Pharmacy, University of New Mexico Health \\ Sciences Center, Albuquerque, NM, USA \\ bepartment of Pharmacology and Toxicology, Boonshoft School of Medecine, Wright State \\ University, Dayton, OH, USA
}

\section{Abstract}

Hypotension in aryl hydrocarbon receptor knockout mice $\left(\mathrm{ahr}^{--}\right)$is mediated, in part, by a reduced contribution of angiotensin (Ang) II to basal blood pressure (BP). Since AHR is highly expressed in endothelial cells (EC), we hypothesized that EC-specific $\mathrm{ahr}^{-1-}\left(\mathrm{EC}_{\mathrm{ahr}}{ }^{-l-}\right)$ mice would exhibit a similar phenotype. We generated EC $a h^{-1-}$ mice by crossing AHR floxed mice $\left(a h r^{f x / f x}\right)$ to mice expressing Cre recombinase driven by an EC-specific promoter. BP was assessed by radiotelemetry prior to and following an acute injection of Ang II or chronic treatment with an angiotensin converting enzyme inhibitor (ACEi). ECahr ${ }^{-1-}$ mice were hypotensive (ECahr ${ }^{+/+}$: $\left.116.1 \pm 1.4 ; \mathrm{ECahr}^{-1-}: 107.4 \pm 2.0 \mathrm{mmHg}, \mathrm{n}=11, \mathrm{p}<0.05\right)$ and exhibited significantly different responses to Ang II and ACEi. While Ang II increased BP in both genotypes, the increase was sustained in ECahr ${ }^{+/+}$, whereas the increase in ECahr ${ }^{-/-}$mice steadily declined. Area under the curve analysis showed that Ang II-induced increase in diastolic BP (DBP) over 30 min was significantly lower in ECahr ${ }^{-l-}$ mice $\left(\mathrm{EC} a h r^{+/+} 1297 \pm 223 \mathrm{mmHg} / 30 \mathrm{~min} ; \mathrm{ECahr}{ }^{-/-}\right.$AUC: $504 \pm$ $138 \mathrm{mmHg} / 30 \mathrm{~min}, \mathrm{p}<0.05)$. In contrast, while ACEi decreased BP in both genotypes, the subsequent rise in DBP after treatment was significantly delayed in the ECahr ${ }^{-/-}$mice. ECahr ${ }^{-1-}$ mice also exhibited reduced vascular and adipose Ang II type 1 receptor (AT1R) expression, and reduced aortic Ang II-dependent vasoconstriction in the presence of vascular adipose. Taken together these data suggest that hypotension in $\mathrm{ECahr}{ }^{-1-}$ mice results from reduced vascular responsiveness to Ang II that is influenced by AT1R expression and adipose.

\section{Keywords}

Aryl hydrocarbon receptor; endothelial cells; blood pressure; hypotension; angiotensin II; adipose

\footnotetext{
(C) 2011 Elsevier Inc. All rights reserved.

*Corresponding Author: College of Pharmacy, Department of Pharmaceutical Sciences, University of New Mexico, 2703 Frontier NE, MSC09 5360, Albuquerque, NM 87131, Tel: 505-272-0580; fax: 505-272-0704., mwalker@ salud.unm.edu.

Publisher's Disclaimer: This is a PDF file of an unedited manuscript that has been accepted for publication. As a service to our customers we are providing this early version of the manuscript. The manuscript will undergo copyediting, typesetting, and review of the resulting proof before it is published in its final citable form. Please note that during the production process errors may be discovered which could affect the content, and all legal disclaimers that apply to the journal pertain.

Conflict of interest

None
} 


\section{Introduction}

The aryl hydrocarbon receptor (AHR) is a ligand-activated, basic helix-loop-helix/PerARNT-Sim transcription factor involved in the adaptive and toxic responses of xenobiotics [1]. The most potent ligand for AHR is the halogenated aromatic hydrocarbon 2, 3, 7, 8tetrachlorodibenzo-p-dioxin (TCDD). In addition to its conventional role in xenobiotic metabolism, recent studies demonstrate a novel role for AHR in vascular development and physiological homeostasis in the absence of exogenous ligands [2,3]. AHR knockout mice $\left(a h r^{-l-}\right)$ exhibit significant reduction in liver size, which results from the persistence of the fetal ductus venosus after birth. The patency of the ductus venosus greatly reduces the portal blood supply, and the failure of this vessel to close is dependent on AHR expression solely in vascular endothelial cells (EC) [4-7]. Beyond its role in vascular development, the AHR also is involved in cardiac development and blood pressure regulation. AHR deficient mice develop cardiac hypertrophy and fibrosis, correlated with an increased size of cardiomyocytes $[2,3]$.

Evidence for the role of AHR in blood pressure regulation has been studied by a number of laboratories. In one study, eight-month-old $a h^{-l-}$ mice are hypotensive, associated with a decreased cardiac output caused by diminished stroke volume [2]. In another study, threemonth-old $\mathrm{ahr}^{-1-}$ mice are also hypotensive with mean arterial pressure (MAP) and systolic (SBP) and diastolic blood pressures (DBP) significantly lower during the entire $24 \mathrm{hr}$ light/ dark cycle [8]. Although both endothelial nitric oxide synthase (eNOS) and its product, nitric oxide (NO), a potent vasodilator, are upregulated in the aorta of $\mathrm{ahr}^{-1-}$ mice, the increased NO does not mediate the resultant hypotension. Rather, hypotension in $\mathrm{hhr}^{-/-}$ mice is mediated, in part, by a decrease in the contribution of the vasoconstrictor, angiotensin (Ang) II, to basal vascular tone. The $a h r^{-/-}$mice are significantly less responsive to a decrease in blood pressure when Ang II formation is inhibited, using the angiotensin converting enzyme (ACE) inhibitor, captopril. These data suggest that Ang II contributes significantly less to maintaining basal blood pressure, compared to $a h^{+/+}$mice. Interestingly, however, indices of renin-angiotensin system (RAS) activity, including plasma renin and ACE activities, and plasma Ang II levels, are normal, suggesting that hypotension in $a h r^{-1-}$ mice may be due to an attenuation of Ang II signaling [8].

In addition to the classic circulating components of the RAS, localized tissue RAS also has been identified in numerous tissues, including the heart, brain, blood vessels, and adipose [9, 10]. Angiotensinogen, the precursor of Ang II, is secreted by white adipose tissue and all the components of the RAS are localized in rat and human adipose [11-13]. The perivascular adipose tissue (PVAT) is interspersed with vasa vasorum and transmits secreted factors that act in a paracrine manner on the underlying blood vessels to modulate vascular tone and contribute to blood pressure regulation. These secreted factors include vasodilators, such as adipocyte-derived relaxing factor, $\mathrm{Ang}_{1-7}$, hydrogen peroxide, and others [14-16], as well as vasoconstrictors, including Ang II and superoxide anion [17, 18]. Therefore, adipose is a major vasoregulator of blood pressure, in part, by contributing to overall RAS activity in the blood vessels.

Since AHR is highly expressed in the endothelium, and endothelial AHR is required for normal vascular development, it seemed logical to investigate the contribution of endothelial AHR to blood pressure regulation. To this end, we generated ECahr ${ }^{-l-}$ mice using Cre-lox recombination to elucidate the mechanism by which AHR in the endothelium modulates blood pressure. We hypothesized that loss of AHR in EC will attenuate Ang II-dependent signaling resulting in hypotension. 


\section{Methods}

\subsection{Mouse models}

Mice expressing the $a h r$ floxed allele $\left(a h r^{f x / f x}\right.$ ) were crossed to mice expressing a Cre transgene driven by the Tie2 kinase promoter enhancer (Tek) (CreTek, strain name: B6.Cg$\operatorname{Tg}$ (Tek-cre)12FlvJ; (The Jackson Laboratory, Bar Harbor, ME) [19, 20]. Mice homozygous for the floxed allele and hemizygous for the Cre transgene $\left(a h r^{f x / f x} \mathrm{Cre}^{\mathrm{Tek}}\right)$ were obtained by crossing male $a h r^{f x /+} \mathrm{Cre}^{\mathrm{Tek}}$ mice to female $a h r^{f x / f x}$ mice. Littermates that were Cre negative were used as genetic controls. Because $\mathrm{Cre}^{\mathrm{Tek}}$ activity results in the deletion of floxed targets in the female germ line, male mice expressing the $a h r r^{f x / f x}$ allele and the $\mathrm{Cre}^{\mathrm{Tek}}$ transgene were used to transmit $\mathrm{Cre}^{\mathrm{Tek}}$ to the offspring. Only male mice were used in subsequent experiments. All animal protocols were approved by the University of New Mexico Animal Care and Use Committee and the investigation conforms to the Guide for the Care and Use of Laboratory Animals published by the U. S. National Institutes of Health (NIH Publication No. 85-23, revised 1996).

\subsection{Assessment of ahr excision}

PCR analysis was used to genotype for the Cre transgene using DNA isolated from tail snips. The reaction contained $0.6 \mu \mathrm{M}$ of each primer (Table 1) and $0.05 \mathrm{U} / \mu \mathrm{l} \mathrm{Tag}$ Polymerase (Promega, Madison, WI, USA), and $1 \mathrm{X}$ buffer (Epicentre Biotechnologies, Madison, WI, USA). PCR was carried out for 39 cycles $\left(94^{\circ} \mathrm{C} / 1 \mathrm{~min} ; 55^{\circ} \mathrm{C} / 1 \mathrm{~min} ; 72^{\circ} \mathrm{C} / 2\right.$ mins). A 450-bp band confirmed the presence of the Cre transgene. Analysis of $a h r f^{f x} / f x$ excision was carried out by multiplex PCR using $1 \mu \mathrm{M}$ of two forward primers and one reverse primer (Table 1S, supplemental data), and $0.025 \mathrm{U} / \mu 1$ Taq Polymerase (Promega), 1X PE Buffer II (Applied Biosystems, Foster City, CA,USA), $2 \mathrm{mM} \mathrm{MgCl}_{2}$, and $0.2 \mathrm{mM}$ dNTPs. PCR was carried out for 29 cycles $\left(95^{\circ} \mathrm{C} / 30 \mathrm{~s} ; 60^{\circ} \mathrm{C} / 30 \mathrm{~s} ; 72^{\circ} \mathrm{C} / 30 \mathrm{~s}\right)$.

\subsection{Assessment of endothelial AHR expression}

Aortas were fixed in 10\% neutral-buffered formalin and embedded in paraffin. Five micron sections were immersed in $1 \mathrm{X}$ Tris-EDTA buffer at $95^{\circ} \mathrm{C}$ for $15 \mathrm{~min}$ for antigen retrieval. Sections were then treated with $3 \%$ hydrogen peroxide to block endogenous peroxidase activity, followed by blocking with $10 \%$ goat serum. Mouse monoclonal anti-AHR antibody (Santa Cruz Biotechnology, Santa Cruz, CA, USA) was applied (1:200) overnight at $4^{\circ} \mathrm{C}$. After washing, a secondary antibody, goat anti-mouse conjugated to horseradish peroxidase (SouthernBiotech, Birmingham, AL, USA), was applied for $1 \mathrm{~h}$ at room temperature (1:200). Slides were washed, stained with 3, 3'-diaminobenzidine tetrahydrochloride solution (Vector Laboratories, Burlingame, CA, USA) for $5 \mathrm{~min}$, and counterstained with methyl green. Sections treated only with second antibody were used as negative controls.

\subsection{In vivo analysis of blood pressure}

Arterial blood pressure and heart rate were measured using radiotelemetry (Data Sciences International, St. Paul, MN, USA) as described [21], using PA-C10 telemeters. Mice were allowed to recover from surgery for $7 \mathrm{~d}$ prior to data collection. Basal blood pressure, including systolic, diastolic, mean and pulse arterial blood pressure, and heart rate were collected for $7 \mathrm{~d}$ before drug treatments began. Blood pressure was recorded for $10 \mathrm{~s}$ every 15 min during baseline measurements and chronic drug treatment, or for $10 \mathrm{~s}$ every $1 \mathrm{~min}$ for $30 \mathrm{~min}$ starting $5 \mathrm{~min}$ after prazosin, hexamethonium, or Ang II injection.

\subsection{Drug treatments}

To determine the effects of Ang II on blood pressure, mice were treated with $4 \mathrm{mg} / \mathrm{kg}$ captopril (angiotensin converting enzyme inhibitor, ACEi) in the drinking water for $5 \mathrm{~d}$ 
followed by a $4 \mathrm{~d}$ washout [22]. To further elucidate the contribution of Ang II to blood pressure, mice were subsequently challenged with an i.p. injection of Ang II $(30 \mu \mathrm{g} / \mathrm{kg})$. Prazosin $(1 \mathrm{mg} / \mathrm{kg})$ or hexamethonium $(30 \mathrm{mg} / \mathrm{kg})$ was injected i.p. into conscious animals to assess acute responses in blood pressure and heart rate [23], while $\mathrm{N}^{\omega}$-nitro-L-arginine (LNNA) was administered in the drinking water $(250 \mathrm{mg} / \mathrm{L})$ to assess chronic changes in blood pressure for $2 \mathrm{wk}$ followed by a $1 \mathrm{wk}$ washout [24]. In all experiments blood pressure was monitored prior to, during and after drug treatments. All drugs were purchased from Sigma-Aldrich (St. Louis, MO, USA).

\subsection{Urine collection and analysis}

$\mathrm{ECahr}^{-/-}$and ECahr ${ }^{+/+}$mice were placed into metabolic mouse cages, one animal per cage, with access to food and water ad libitum. Mice were acclimated to the cage for $24 \mathrm{~h}$ and urine generated during this period was discarded. Then, $24 \mathrm{~h}$ urine samples were collected twice in the subsequent $48 \mathrm{~h}$ and pooled. Urine was analyzed for osmolality using the Vapro $^{\mathrm{TM}}$ Vapor Pressure Osmometer, model 5520 (Wescor, Inc Biomedical Division, Logan, UT, USA). Urinary nitrate/nitrite levels (NOx) were measured using the Griess colorimetric assay (Cayman Chemical, MI, USA).

\subsection{Analysis of plasma ACE, renin activity, and salt balance}

Plasma renin activity (PRA) was determined using a commercial kit (GammaCoat ${ }^{\circledR}$ Plasma Renin Activity ${ }^{125}$ I Kit; DiaSorin, Stillwater, MN) [25]. The PRA assay is a two-step process, where first angiotensin I is generated and second angiotensin I is detected by a radioimmunoassay. PRA is expressed as $\mathrm{ng} / \mathrm{ml} / \mathrm{hr}$ of generated angiotensin I. Plasma ACE activity was determined using a commercial kit (Alpco Diagnostics, Salem, NH, USA). Plasma samples were incubated with a synthetic ACE substrate, ${ }^{3} \mathrm{H}$-hippuryl-glycyl-glycine, and the product, ${ }^{3} \mathrm{H}$ - hippuric acid, was extracted and measured in a beta counter. ACE activity was expressed as Units/Liter. One unit of ACE activity was defined as the amount of enzyme required to release $1 \mu \mathrm{mol}$ of hippuric acid per minute per liter of plasma at $37^{\circ}$ C.

\section{8 mRNA analysis of renin, angiotensinogen, and AT1R from adipose and aorta}

Total RNA was isolated from perirenal visceral white adipose, aortic PVAT, and aortas cleaned of adipose tissue, using Trizol reagent (Invitrogen, Carlsbad, CA, USA). cDNA was synthesized using iScript Select cDNA Synthesis Kit (Bio-Rad Laboratories, Hercules, CA) with the supplied random primers and $250 \mathrm{ng}$ RNA. PCR amplification was performed using an iCycler (Bio-Rad Laboratories) with a reaction mixture comprised of iQ SYBR Green Supermix (Bio-Rad Laboratories) with $500 \mu \mathrm{M}$ of each forward and reverse primer (Table $1 \mathrm{~S}$, supplemental data). Cycle threshold data for both the target gene of interest and control normalization gene, DNA Polymerase II (POL2) for adipose and glyceraldehyde-3phosphate dehydrogenase (GAPDH) for aorta, were used to calculate mean normalized expression as previously described [26].

\subsection{Aortic AT1R protein analysis}

Abdominal aortas, free of PVAT were homogenized in RIPA buffer (Santa Cruz Biotechnology), the homogenate frozen at $-80^{\circ} \mathrm{C}$, thawed, sonicated and centrifuged at $15,000 \times \mathrm{g} 4{ }^{\circ} \mathrm{C}$ for $10 \mathrm{~min}$. Protein concentration in the supernatant was measured using micro BCA protein assay kit (Thermo Scientific, Rockford, IL, USA). A $30 \mu \mathrm{g}$ aliquot of protein was analyzed on a $10 \%$ Tris-HCL polyacrylamide gel for AT1R protein, using rabbit anti-AT1R antibody (Santa Cruz Biotechnology), and GAPDH (Millipore, Billerica, MA, USA) as a normalization control. 


\subsection{Ex vivo analysis of abdominal aortic reactivity}

The abdominal aorta was excised with major skeletal muscles attached, which encased the perivascular fat and aortic vessel and placed in ice-cold physiological saline (PSS) containing $130 \mathrm{nM} \mathrm{NaCl}, 4.7 \mathrm{mM} \mathrm{KCl}, 1.2 \mathrm{mM} \mathrm{KH}_{2} \mathrm{PO}_{4}, 1.2 \mathrm{mM} \mathrm{MgSO} 4,15 \mathrm{mM}$ $\mathrm{NaHCO}_{3}, 5.5 \mathrm{mM}$ glucose, $26 \mu \mathrm{M} \mathrm{CaNa}_{2}$ EDTA, $1.8 \mathrm{mM} \mathrm{CaCl}_{2}, \mathrm{pH}$ 7.4. The skeletal muscle was removed without disrupting the underlying fat tissue, ensuring that similar amounts of fat were present on each vessel. Two - $2 \mathrm{~mm}$ segments were cut from the same region of the abdominal aorta from each mouse either in presence or absence of PVAT and individual rings were suspended in an organ bath containing PSS at $37^{\circ} \mathrm{C}$ bubbled with $21 \%$ $\mathrm{O}_{2}, 6 \% \mathrm{CO}_{2}$, balanced $\mathrm{N}_{2}$. The rings were attached to a force transducer (Grass Technologies, West Warwick, RI, USA) with steel hangers and resting tension was increased step wise to $1.5 \mathrm{~g}$ over $30 \mathrm{~min}$. After equilibration, rings were treated with $\mathrm{KCl}$ $(80 \mathrm{mM})$ for $5 \mathrm{~min}$. Thereafter, rings were treated to $100 \mathrm{nM}$ and $500 \mathrm{nM}$ Ang II. After a final washout, contraction with $10 \mu \mathrm{M}$ phenylephrine (PE) for $5 \mathrm{~min}$ was followed by relaxation with $10 \mu \mathrm{M}$ acetylcholine (ACh) to determine the viability of the rings. Rings with dilation less than $50 \%$ were discarded. All chemicals were purchased from SigmaAldrich.

\subsection{Statistical analysis}

Differences among genotypes were analyzed by student's t-test. The treatment-related changes in blood pressure between genotypes were analyzed by repeated measures, two-way analysis of variance with post hoc Holm-Sidak comparisons; $* P<0.05$ was considered statistically significant in all cases.

\section{Results}

\section{1 ahr excision as determined by PCR and endothelial AHR deletion as determined by immunohistochemistry}

PCR amplification of the $a h r f x / f x$-unexcised allele results in a 140-bp band, while amplification across the $a h r^{f x / f x}$-excised allele amplifies a 180-bp band. PCR amplification of the WT allele, when present, generates a 106-bp band [7]. Our results demonstrated the successful excision of the $a h^{f x / f x}$ allele in organs that contain EC and specifically in conduit and resistance blood vessels, including the aorta and mesenteric arteries, respectively (Fig. 1A). Further, immunohistochemistry confirmed the deletion of AHR protein from the endothelium of the aorta of ECahr $r^{-/-}$mice, compared to ECahr ${ }^{+/+}$mice (Fig. 1B).

\subsection{Basal blood pressure, activity, and organ weights}

Blood pressure of ECahr ${ }^{-l-}$ and ECahr ${ }^{+/+}$littermates was measured by radiotelemetry. The ECahr $r^{-/-}$mice exhibited significantly lower SBP and DBP, compared to EC $a h r^{+/+}$mice (Fig. 2A). Pulse pressure (data not shown) and heart rate were normal (Fig. 2B). The decrease in blood pressure in ECahr ${ }^{-1}$ mice was evident throughout the entire $24 \mathrm{~h}$ light/ dark cycle, although the circadian pattern of MAP exhibited a normal increase during the night wakeful period (Fig. 2C). The level of activity was comparable between ECahr ${ }^{-l-}$ and $\mathrm{EC} a h r^{+/+}$mice during the $24 \mathrm{~h}$ light/dark cycle (Fig. 2D). Finally, ECahr $r^{-1-}$ mice exhibited a decreased liver weight and cardiac hypertrophy accompanied by renal enlargement (Table 1 ), but did not exhibit any changes in weight of adipose tissue (Table 2S, supplemental data).

\subsection{Inhibition of NOS on blood pressure}

To determine the potential contribution of NOS and NO to hypotension in ECahr ${ }^{-1-}$ mice, we treated ECahr $r^{+/+}$and ECahr $r^{-1-}$ mice chronically with the NOS inhibitor, LNNA (250 
$\mathrm{mg} / \mathrm{L}$ ) in drinking water for $2 \mathrm{wk}$ and assessed changes in blood pressure by radiotelemetry. There was an increase in MAP during LNNA treatment in both ECahr $r^{-/}$and ECahrt/+ mice, and the relative change in MAP was similar between the two genotypes (Fig. 3A and B). After treatment ended, MAP returned to baseline in both genotypes. To further determine if vascular eNOS or systemic NO levels were altered, we measured aortic eNOS mRNA and protein, and urinary NOx. Aortic eNOS expression and urinary NOx levels did not different between ECahr ${ }^{-/-}$and ECahr ${ }^{+/+}$mice (Fig. 1S, supplemental data).

\subsection{Sympathetic nervous system activity and intrinsic heart rate}

To determine if a reduction in the sympathetic contribution to vascular tone or a lower intrinsic heart rate drives the hypotension in the $\mathrm{ECahr} r^{-1-}$ mice, we assessed changes in MAP and heart rate in ECahr $r^{-/}$and ECahr ${ }^{+/+}$mice, following an acute exposure to prazosin, an $\alpha 1$ adrenoceptor antagonist, or to hexamethonium, a ganglionic blocker. We found that MAP decreased significantly more in the ECahr ${ }^{-1-}$ mice after prazosin $\left(\mathrm{ECahr}^{+/+} ;-5.3 \pm 1.7 \mathrm{mmHg}\right.$; ECahr ${ }^{-/-}:-11.7 \pm 2.3 \mathrm{mmHg}, \mathrm{n}=4 /$ genotype, $\left.\mathrm{p}<0.05\right)$ and hexamethonium treatment $\left(\mathrm{ECahr}^{+/+} ;-18.2 \pm 1.8 \mathrm{mmHg}\right.$; ECahr ${ }^{--}:-25.8 \pm 1.5 \mathrm{mmHg}$, $\mathrm{n}=4 /$ genotype, $\mathrm{p}<0.05)$, compared to ECahr ${ }^{+/+}$mice, suggesting that sympathetic contribution to vascular tone is increased (Fig. 2S, supplemental data). However, the intrinsic heart rate observed following hexamethonium treatment was similar between genotypes.

\subsection{Functional assessment of Ang II responsiveness in vivo}

To determine if hypotension in the $\mathrm{ECahr}^{-l-}$ mice was due to reduced responsiveness to Ang II in vivo, we challenged ECahr ${ }^{-/-}$and ECahr ${ }^{+/+}$mice with a bolus dose of Ang II (30 $\mu \mathrm{g} / \mathrm{kg}$ ) and recorded the blood pressure response starting $5 \mathrm{~min}$ after injection. An immediate, robust response to Ang II was demonstrated by a comparable increase in MAP in both genotypes during the first $2 \mathrm{~min}\left(\mathrm{ECahr} r^{-{ }^{-}}: 150 \pm 2 \mathrm{mmHg}\right.$; ECahr ${ }^{+/+} 140 \pm 10$ $\mathrm{mmHg}$ ) (Fig. 4). However, the subsequent change in blood pressure after the first $5 \mathrm{~min}$ differed considerably between genotypes. MAP in ECahr ${ }^{+/+}$mice remained highly elevated $(150 \pm 8 \mathrm{mmHg}$ at $5 \mathrm{~min})$ with only a very modest decrease after $30 \mathrm{~min}(137 \pm 3 \mathrm{mmHg})$. In contrast, the MAP in ECahr $r^{-1-}$ mice exhibited a steady decline $(138 \pm 2 \mathrm{mmHg}$ at $5 \mathrm{~min})$ with significantly lower MAP values being evident as early as $9 \min (136 \pm 2 \mathrm{mmHg})$ and dropping further by $30 \mathrm{~min}(122 \pm 4 \mathrm{mmHg})$ (Fig. 4A). Interestingly, the SBP response was similar between ECahr ${ }^{-1}$ and ECahr ${ }^{+/+}$mice, although SBP did decrease slightly faster in the ECahr ${ }^{-l-}$ mice reaching significantly lower values by $20 \mathrm{~min}$ (Fig. 4B). In contrast, the DBP response was significantly diminished in $\mathrm{EC} a \mathrm{hr}^{-/-}$mice across all time points beginning as early as $3 \mathrm{~min}$ (Fig. 4C). Area under the curve analysis following Ang II injection showed that the increase in DBP was significantly attenuated in ECahr ${ }^{-/-}$mice $\left(\mathrm{ECahr}{ }^{-l-}\right.$ AUC: $504 \pm 138 \mathrm{mmHg} / 30 \mathrm{~min} ; \mathrm{ECahr}^{+/+}{ }_{\text {AUC: }} 1297 \pm 223 \mathrm{mmHg} / 30 \mathrm{~min}$, $\mathrm{p}<0.05)$, while the increase in SBP was not different between genotypes (ECahr ${ }^{-1-}$ AUC: 702 $\pm 70 \mathrm{mmHg} / 30 \mathrm{~min}$; $\mathrm{ECahr^{+/+ }} \mathrm{AUC}: 1106 \pm 150 \mathrm{mmHg} / 30 \mathrm{~min}$, (p>0.05)(Fig. 4D).

\section{6 Inhibition of RAS on blood pressure}

To further elucidate the contribution of the RAS to the hypotension in $\mathrm{ECahr}{ }^{-1-}$ mice, we investigated the responsiveness of ${\mathrm{EC} a h r^{-/-}}^{-}$and $\mathrm{EC} a h r^{+/+}$mice to an ACEi. We found that captopril significantly decreased MAP, SBP and DBP in mice of both genotypes after $5 \mathrm{~d}$ of treatment. While the decrease tended to be greater in $\mathrm{ECahr}^{+/+}$mice during the first days of treatment, it was not statistically different than the drop seen in ECahr ${ }^{-1}$ mice (Fig. 5A, B and C). Interestingly, during the 4 days of washout after drug treatment stopped, MAP and DBP remained significantly lower and did not return to baseline in ECahr ${ }^{-/-}$mice, compared to ECahr $r^{+++}$mice (Fig. 5A, C and D). To determine if any components of the systemic RAS or indices of RAS activity, such as salt and water balance were altered, we 
evaluated PRA, ACE activity, plasma electrolytes and urine osmolality. We found that all, except plasma K, were similar between ECahr ${ }^{-/-}$and ECahr ${ }^{+/+}$mice, and although plasma $\mathrm{K}$ was slightly reduced in $\mathrm{ECahr}{ }^{--}$mice it was still within normal physiological limits (4.0 $-7.0 \mathrm{mM}$ ) (Table 2).

\section{7 mRNA analysis of RAS components from adipose and aorta}

To determine if tissue RAS components were altered in their expression, we measured mRNA of renin, angiotensinogen (Agt) and AT1R in visceral white adipose, aortic PVAT, and in aortas cleaned of adipose tissue. We found that Agt mRNA was significantly increased in aortic PVAT in ECahr ${ }^{-1-}$ mice, but not altered in either visceral white adipose or the aorta proper, compared to ECahr ${ }^{+/+}$mice (Figure 6A). In addition, both renin and AT1R mRNA was significantly reduced in visceral adipose from $\mathrm{ECahr}^{-/-}$mice, compared to ECahr ${ }^{+/+}$mice, but not altered in aortic PVAT or the aorta (Figure 6B and C).

\subsection{AT1R protein expression and aortic reactivity to Ang II}

To determine if the decreased responsiveness to Ang II could result from decreased protein expression of the AT1R ECahr ${ }^{-1-}$ mice, we measured AT1R protein expression in aortas cleaned of adipose. We found that AT1R protein expression in the aorta free of adipose was significantly lower in the ECahr $r^{-/-}$, compared to ECahr $r^{+/+}$mice (Fig. 7A and B). To further determine if vascular reactivity to Ang II was decreased in ECahr ${ }^{-/-}$mice, and if this was influenced by the presence of PVAT, we examined ex vivo abdominal aortic reactivity to two different doses of Ang II in the presence and absence of aortic PVAT. We found that responsiveness of the abdominal aorta to Ang II was completely normal in ECahr ${ }^{-1-}$ mice in the absence of PVAT (Fig. 8A). However, we found that the responsiveness of the abdominal aorta to Ang II was significantly attenuated in $\mathrm{ECahr}^{-1}$ mice in the presence of PVAT (ECahr ${ }^{+/+} ; 0.2 \pm 0.04$; ECahr $r^{-/-}: 0.1 \pm 0.01$, n=11/genotype, p<0.05) (Fig. 8B).

\section{Discussion}

The findings from our study show for the first time that AHR in the endothelium is critically involved in blood pressure regulation and is required to maintain normal basal levels of blood pressure. Notably, ECahr ${ }^{-1-}$ mice are significantly hypotensive and this phenotype is associated with alter gene expression of tissue RAS components as well as decreased protein expression of vascular AT1R. Further, the hypotension is mediated, in part, by a reduction in vasoconstrictive responsiveness to Ang II, measured both in vivo and ex vivo. The blood pressure phenotype in ECahr ${ }^{-1}$ mice is nearly identical to that observed in the global AHR knockout mice, demonstrating that endothelial-expressed AHR is a critical regulator of vascular control of blood pressure and this function cannot be compensated by the normal expression of AHR in other tissues or cell types.

Hypotension can have many physiological etiologies, such as decreases in the contribution of the sympathetic nervous system to vasoconstriction or increases in vascular eNOS expression and NO production. For example, genetic deletion of $\alpha 1$ adrenergic receptors or transgenetic overexpression of vascular eNOS both produces hypotension [27-29].

However, our data rule out these two possible mechanisms in contributing to the hypotension observed in ECahr ${ }^{-1}$ mice. Treatment of ECahr ${ }^{-1}$ mice with the $\alpha 1$ adrenoceptor blocker, prazosin, or the ganglionic blocker, hexamethonium, significantly reduce blood pressure in ECahr ${ }^{-/}$mice, suggesting that sympathetic nervous system control of blood pressure is actually enhanced in ECahr $r^{-1-}$ mice, rather than reduced. Additionally, neither eNOS expression nor NOx levels are increased in ECahr ${ }^{-/-}$mice and chronic NOS inhibition increases blood pressure to the same degree in both genotypes. Taken together these data suggest that increased NO is not responsible for the hypotension 
in ECahr $r^{-1}$ mice. This observation is consistent with that observed for the global AHR knockout mice [8].

Another mechanism that may mediate hypotension in $\mathrm{ECahr^{-1 }}$ mice is a reduction in RAS signaling. Several studies have demonstrated the requirement for the RAS in maintaining basal blood pressure within a normal range. Mice that lack angiotensinogen, ACE, or AT1R, have all been shown to be hypotensive [30-32], and our data clearly demonstrate a decrease of Ang II signaling both in vivo and ex vivo. In vivo exposure of ECahr ${ }^{-/-}$and $\mathrm{EC} a \mathrm{hr}^{+/+}$ mice to an acute dose of Ang II produces an immediate rise in blood pressure in both genotypes; however, this increase is not sustained in the $\mathrm{ECahr}^{-1-}$ mice. Further, the steady decline in DBP in ECahr ${ }^{-1-}$ mice after acute Ang II injection suggests a significant reduction in the duration of the vasoconstrictor response. In addition, chronic exposure of $\mathrm{EC} a h r^{-/-}$and ECahr ${ }^{+/+}$mice to an ACEi reduces blood pressure in both genotypes; however, the subsequent increase in DBP after drug treatment is stopped is significantly attenuated in ECahr ${ }^{-1-}$ mice, further suggesting a decrease in response to Ang II-mediated vasoconstriction. These in vivo data are further supported by ex vivo vasoreactivity data that show abdominal aortas from ECahr ${ }^{-1}$ mice are significantly less responsive to Ang IImediated constriction in the presence of PVAT. It is notable that although Ang II responsiveness is reduced, other indices of RAS activity are normal, including PRA and ACE activity, renin, angiotensinogen, and plasma Ang II. Taken together these data suggest that downstream signaling of Ang II is reduced.

One mechanism by which Ang II-mediated vasoconstriction could be reduced is by a reduction in receptor expression. Both pharmacological blockade of AT1R and genetic deletion of AT1R reduce blood pressure [32-34]. Our data show that loss of endothelial AHR significantly reduces white adipose expression of AT1R mRNA as well as aortic expression of AT1R protein. The mechanism by which AHR deficiency reduces AT1R expression is not known. The AHR regulates gene expression via binding to dioxin response elements (DRE) containing the core recognition motif 5'-GCGTG-3' [35]. Putative DREs are located in the promoter sequence of both the mouse AT1a and AT1b receptors, supporting the plausibility that expression of the mouse AT1R could be directly regulated by AHR. This is further supported by the fact that activation of the AHR by exogenous ligands sensitizes mice to Ang II-mediated hypertension [36], and induces AT1R mRNA expression in mesenteric arteries (unpublished data). Further, physiological shear stress has been shown to activate the AHR [37-39], and to increase AT1R expression [40], providing indirect evidence that AHR may contribute to the regulation of AT1R expression. Additionally, the AHR interacts with several other transcription factors including E2F1, TFIIE, TFIIB, as well as coactivators like CREB-binding protein, $\mathrm{CBP} / \mathrm{p} 300$ and nuclear receptor-interacting protein 1 (RIP140) [41, 42] and thus alteration in AT1R expression could result from crosstalk with other signaling pathways.

Despite the observed reduction in vascular AT1R expression, this is unlikely to be the sole explanation for the hypotensive phenotype observed in ECahr ${ }^{-1-}$ mice, since vasoreactivity to Ang II ex vivo is not significantly attenuated in the absence of PVAT. Rather, a significant decrease in vasoconstriction to Ang II is only observed in ECahr ${ }^{-/-}$mice in the presence of PVAT. It is possible that loss of AHR from the endothelium might alter the paracrine signaling between that occurs between the microcirculation and the adipose, including PVAT. Both renin and AT1R mRNA were significantly decreased in expression in visceral white adipose, which might contribute to a reduction in Ang II release from the adipose and a shift in the balance between vasoconstrictors and vasodilators released from adipose. It has been shown that stimulation of adipose AT1R by Ang II acts in a feedforward mechanism to increase adipocyte release of Ang II [49]. It is also possible the loss of AHR from the endothelium increases vasodilators released from adipose. These dilators could 
include the newly discovered hydrogen sulphide gas $\left(\mathrm{H}_{2} \mathrm{~S}\right)$ generated by cystathionine gamma lyase enzyme (CSE) $[43,44]$ as well as adipocyte-derived relaxing factor, adiponectin, leptin, omentin, and interleukin-6 [45-47]. Taken together, the deregulation of the RAS in adipose associated with diminished AT1R expression in the vasculature might drive the subsequent hypotension observed in the $\mathrm{ECahr}^{-/-}$mice.

The $a h r$ floxed mice $\left(a h r^{f x} / f x\right)$, which were our genetic control in these studies, harbor the low affinity, ahr ${ }^{\mathrm{d}}$ allele, derived from the DBA-2 strain. In contrast, the $a h r^{+/+}$mice used as a genetic control in previously published studies harbor the high affinity, ahr ${ }^{\mathrm{b} 1}$ allele. Thus, we cannot directly compare the blood pressure phenotype of the ECahr $r^{-l-}$ mice and $a r^{-l-}$ mice. Nevertheless, the blood pressure phenotype of the ECahr ${ }^{-1-}$ and the $a h r^{-I-}$ mice, compared to their respective wildtype controls, shares many similarities. First, hypotension is a hallmark of both of these mouse models [8], where the $a \mathrm{hr}^{-1-}$ mice exhibit a $14 \%$ lower MAP, compared to $a h r^{+/+}$mice, while ECahr ${ }^{-/-}$mice exhibit an $8 \%$ lower MAP, compared to ECahr ${ }^{+/+}$mice. Second, the resultant hypotension in both ECahr $r^{-1-}$ and the $a h r^{-1-}$ mice is not mediated by an increase in NO production. Third, both ECahr ${ }^{-/-}$and the $a \mathrm{hr}^{-1-}$ mice exhibit a reduced responsiveness to the RAS without apparent changes in indices of RAS activation, suggesting that the RAS contributes less in maintaining basal blood pressure in both the ECahr ${ }^{-/-}$and $a h r^{-1-}$ mice [8].

Finally, ECahr $r^{--}$and $\mathrm{ahr}^{-1-}$ mice also share some fundamental similarities related to in changes in organ weight. The $\mathrm{ahr}^{-l-}$ mice exhibit decreased liver size, as well as increased weight of heart and kidneys $[8,52]$. In our study, ECahr ${ }^{-l-}$ mice also exhibit a decreased liver size, as well as increased weight of heart and kidneys. While the reduction in liver weight has been attributed to the persistent ductus venosus and reduced hepatocyte size [5, 6], the reasons for the increases in heart and kidney weight have not been firmly established. The increased heart weight might reflect a compensatory response to increase cardiac output in an attempt to normalize blood pressure, hence a physiological hypertrophy [2], while increased kidney weight may result from altered developmental vascularization [5]. Nonetheless, our study demonstrates that these organ weight changes result from loss of AHR solely from the endothelium.

The mechanism by which AHR regulates blood pressure remains to be fully determined; however, our study establishes that AHR expression in the endothelium is particularly critical to normal vascular responsiveness to Ang II and thus basal blood pressure control. Since the RAS is not only essential to the physiological regulation of basal blood pressure but also a primary pathological mediator of hypertension, the AHR signaling pathway could represent an important novel mechanism to influence RAS activity and to control blood pressure. Future studies are needed, however, to identify the specific AHR genes that mediate these changes in RAS responsiveness and that influence the vascular responsiveness in the context of adipose tissue.

\section{Supplementary Material}

Refer to Web version on PubMed Central for supplementary material.

\section{ABBREVIATIONS}

$\begin{array}{ll}\text { AHR } & \text { Aryl hydrocarbon receptor } \\ \text { TCDD } & \text { 2,3,7,8-tetrachlorodibenzo- } p \text {-dioxin } \\ \text { Cre } & \text { Cre-recombinase }\end{array}$




$\begin{array}{ll}\text { EC } & \text { Endothelial cell } \\ \boldsymbol{A h} \boldsymbol{h} f \boldsymbol{f} / f \boldsymbol{x} & \text { Floxed } a h r \text { allele } \\ \text { ACE } & \text { Angiotensin converting enzyme } \\ \text { ACEi } & \text { Angiotensin converting enzyme inhibitor } \\ \text { Agt } & \text { Angiotensinogen } \\ \text { Ang II } & \text { Angiotensin II } \\ \text { MAP } & \text { Mean arterial pressure } \\ \text { BP } & \text { Blood pressure } \\ \text { NOx } & \text { Nitrates/nitrites } \\ \text { NO } & \text { Nitric oxide } \\ \text { RAS } & \text { Renin-angiotensin system } \\ \text { AT1R } & \text { Angiotensin 1 receptor } \\ \text { PRA } & \text { Plasma renin activity } \\ \text { PVAT } & \text { Perivascular adipose tissue }\end{array}$

\section{Acknowledgments}

This study was supported by a grant from the National Institutes of Health [R01 HL078914 to M.K.W.]. The authors thank Mary T. Walsh for her assistance, and Dr. Nancy L. Kanagy for her technical assistance.

\section{References}

1. McMillan BJ, Bradfield CA. The aryl hydrocarbon receptor sans xenobiotics: endogenous function in genetic model systems. Mol Pharmacol. 2007; 72:487-498. [PubMed: 17535977]

2. Vasquez A, Atallah-Yunes N, Smith FC, You X, Chase SE, Silverstone AE, et al. A role for the aryl hydrocarbon receptor in cardiac physiology and function as demonstrated by AhR knockout mice. Cardiovasc Toxicol. 2003; 3:153-163. [PubMed: 14501033]

3. Thackaberry EA, Gabaldon DM, Walker MK, Smith SM. Aryl hydrocarbon receptor null mice develop cardiac hypertrophy and increased hypoxia-inducible factor-1alpha in the absence of cardiac hypoxia. Cardiovasc Toxicol. 2002; 2:263-274. [PubMed: 12665660]

4. Walisser JA, Bunger MK, Glover E, Harstad EB, Bradfield CA. Patent ductus venosus and dioxin resistance in mice harboring a hypomorphic Arnt allele. J Biol Chem. 2004; 279:16326-16331. [PubMed: 14764592]

5. Lahvis GP, Lindell SL, Thomas RS, McCuskey RS, Murphy C, Glover E, et al. Portosystemic shunting and persistent fetal vascular structures in aryl hydrocarbon receptor-deficient mice. Proc Natl Acad Sci U S A. 2000; 97:10442-10447. [PubMed: 10973493]

6. Lahvis GP, Pyzalski RW, Glover E, Pitot HC, McElwee MK, Bradfield CA. The aryl hydrocarbon receptor is required for developmental closure of the ductus venosus in the neonatal mouse. Mol Pharmacol. 2005; 67:714-720. [PubMed: 15590894]

7. Walisser JA, Glover E, Pande K, Liss AL, Bradfield CA. Aryl hydrocarbon receptor-dependent liver development and hepatotoxicity are mediated by different cell types. Proc Natl Acad Sci U S A. 2005; 102:17858-17863. [PubMed: 16301529]

8. Zhang N, Agbor LN, Scott JA, Zalobowski T, Elased KM, Trujillo A, et al. An activated reninangiotensin system maintains normal blood pressure in aryl hydrocarbon receptor heterozygous mice but not in null mice. Biochem Pharmacol. 80:197-204. [PubMed: 20359465] 
9. Stoll M, Steckelings UM, Paul M, Bottari SP, Metzger R, Unger T. The angiotensin AT2-receptor mediates inhibition of cell proliferation in coronary endothelial cells. J Clin Invest. 1995; 95:651657. [PubMed: 7860748]

10. Vaughan DE, Lazos SA, Tong K. Angiotensin II regulates the expression of plasminogen activator inhibitor-1 in culture endothelial cells. A potential link between the renin-angiotensin system and thrombosis. J Clin Invest. 1995; 95:995-1001. [PubMed: 7884001]

11. Engeli S, Negrel R, Sharma AM. Physiology and Pathophysiology of the Adipose Tissue ReninAngiotensin System. Hypertension. 2000; 35:1270-1277. [PubMed: 10856276]

12. Giacchetti G, Sechi LA, Griffin CA, Don BR, Mantero F, Schambelan M. The tissue reninangiotensin system in rats with fructose- induced hypertension: overexpression of type 1 angiotensin II receptor in adipose tissue. Journal of Hypertension. 2000; 18:695-702. [PubMed: 10872553]

13. Engeli S, Gorzelniak K, Kreutz R, Runkel N, Distler A, Sharma AM. Co-expression of reninangiotensin system genes in human adipose tissue. Journal of Hypertension. 1999; 17:555-560. [PubMed: 10404958]

14. Verlohren S, Dubrovska G, Tsang S-Y, Essin K, Luft FC, Huang Y, et al. Visceral Periadventitial Adipose Tissue Regulates Arterial Tone of Mesenteric Arteries. Hypertension. 2004; 44:271-276. [PubMed: 15302842]

15. Gao YJ, Lu C, Su LY, Sharma AM, Lee RMKW. Modulation of vascular function by perivascular adipose tissue: the role of endothelium and hydrogen peroxide. British Journal of Pharmacology. 2007; 151:323-331. [PubMed: 17384669]

16. Lã-hn M, Dubrovska G, Lauterbach B, Luft FC, Gollasch M, Sharma AM. Periadventitial fat releases a vascular relaxing factor. The FASEB Journal. 2002; 16:1057-1063. [PubMed: 12087067]

17. Massiã\%ora F, Bloch-Faure M, Ceiler D, Murakami K, Fukamizu A, Gasc J-M, et al. Adipose angiotensinogen is involved in adipose tissue growth and blood pressure regulation. The FASEB Journal. 2001; 15:2727-2729. [PubMed: 11606482]

18. Gao Y-J, Takemori K, Su L-Y, An W-S, Lu C, Sharma AM, et al. Perivascular adipose tissue promotes vasoconstriction: the role of superoxide anion. Cardiovascular Research. 2006; 71:363373. [PubMed: 16756966]

19. Koni PA, Joshi SK, Temann UA, Olson D, Burkly L, Flavell RA. Conditional vascular cell adhesion molecule 1 deletion in mice: impaired lymphocyte migration to bone marrow. J Exp Med. 2001; 193:741-754. [PubMed: 11257140]

20. Postic C, Shiota M, Niswender KD, Jetton TL, Chen Y, Moates JM, et al. Dual roles for glucokinase in glucose homeostasis as determined by liver and pancreatic beta cell-specific gene knock-outs using Cre recombinase. J Biol Chem. 1999; 274:305-315. [PubMed: 9867845]

21. Lund AK, Agbor LN, Zhang N, Baker A, Zhao H, Fink GD, et al. Loss of the aryl hydrocarbon receptor induces hypoxemia, endothelin-1, and systemic hypertension at modest altitude. Hypertension. 2008; 51:803-809. [PubMed: 18212270]

22. Lund AK, Goens MB, Kanagy NL, Walker MK. Cardiac hypertrophy in aryl hydrocarbon receptor (AhR) null mice is correlated with elevated angiotensin II, endothelin-1 and mean arterial blood pressure. Toxicol Appl Pharmacol. 2003; 193:177-187. [PubMed: 14644620]

23. Chen Y, Joaquim LF, Farah VM, Wichi RB, Fazan R Jr, Salgado HC, et al. Cardiovascular autonomic control in mice lacking angiotensin AT1a receptors. Am J Physiol Regul Integr Comp Physiol. 2005; 288:R1071-R1077. [PubMed: 15576667]

24. Duling LC, Cherng TW, Griego JR, Perrine MF, Kanagy NL. Loss of alpha2B-adrenoceptors increases magnitude of hypertension following nitric oxide synthase inhibition. Am J Physiol Heart Circ Physiol. 2006; 291:H2403-H2408. [PubMed: 16815979]

25. Senador D, Kanakamedala K, Irigoyen MC, Morris M, Elased KM. Cardiovascular and autonomic phenotype of db/db diabetic mice. Exp Physiol. 2009; 94:648-658. [PubMed: 19218356]

26. Simon P. Q-Gene: processing quantitative real-time RTâ€“PCR data. Bioinformatics. 2003; 19:1439-1440. [PubMed: 12874059] 
27. van Haperen R, de Waard M, van Deel E, Mees B, Kutryk M, van Aken T, et al. Reduction of blood pressure, plasma cholesterol, and atherosclerosis by elevated endothelial nitric oxide. J Biol Chem. 2002; 277:48803-48807. [PubMed: 12364322]

28. Sanbe A, Tanaka Y, Fujiwara Y, Tsumura H, Yamauchi J, Cotecchia S, et al. $\alpha 1$-Adrenoceptors are required for normal male sexual function. British Journal of Pharmacology. 2007; 152:332340. [PubMed: 17603545]

29. Ohashi Y, Kawashima S, Hirata K, Yamashita T, Ishida T, Inoue N, et al. Hypotension and reduced nitric oxide-elicited vasorelaxation in transgenic mice overexpressing endothelial nitric oxide synthase. J Clin Invest. 1998; 102:2061-2071. [PubMed: 9854041]

30. Esther CR Jr, Howard TE, Marino EM, Goddard JM, Capecchi MR, Bernstein KE. Mice lacking angiotensin-converting enzyme have low blood pressure, renal pathology, and reduced male fertility. Lab Invest. 1996; 74:953-965. [PubMed: 8642790]

31. Tsuchida S, Matsusaka T, Chen X, Okubo S, Niimura F, Nishimura H, et al. Murine double nullizygotes of the angiotensin type $1 \mathrm{~A}$ and $1 \mathrm{~B}$ receptor genes duplicate severe abnormal phenotypes of angiotensinogen nullizygotes. J Clin Invest. 1998; 101:755-760. [PubMed: 9466969]

32. Kim HS, Krege JH, Kluckman KD, Hagaman JR, Hodgin JB, Best CF, et al. Genetic control of blood pressure and the angiotensinogen locus. Proc Natl Acad Sci U S A. 1995; 92:2735-2739. [PubMed: 7708716]

33. Iyer SN, Lu D, Katovich MJ, Raizada MK. Chronic control of high blood pressure in the spontaneously hypertensive rat by delivery of angiotensin type 1 receptor antisense. Proceedings of the National Academy of Sciences of the United States of America. 1996; 93:9960-9965. [PubMed: 8790439]

34. Lu D, Raizada MK, Iyer S, Reaves P, Yang H, Katovich MJ. Losartan Versus Gene Therapy : Chronic Control of High Blood Pressure in Spontaneously Hypertensive Rats. Hypertension. 1997; 30:363-370. [PubMed: 9314418]

35. Swanson HI, Chan WK, Bradfield CA. DNA Binding Specificities and Pairing Rules of the Ah Receptor, ARNT, and SIM Proteins. Journal of Biological Chemistry. 1995; 270:26292-26302. [PubMed: 7592839]

36. Aragon AC, Goens MB, Carbett E, Walker MK. Perinatal 2,3,7,8-tetrachlorodibenzo-p-dioxin exposure sensitizes offspring to angiotensin II-induced hypertension. Cardiovasc Toxicol. 2008; 8:145-154. [PubMed: 18670907]

37. Conway DE, Sakurai Y, Weiss D, Vega JD, Taylor WR, Jo H, et al. Expression of CYP1A1 and CYP1B1 in human endothelial cells: regulation by fluid shear stress. Cardiovasc Res. 2009; 81:669-677. [PubMed: 19126602]

38. Han Z, Miwa Y, Obikane H, Mitsumata M, Takahashi-Yanaga F, Morimoto S, et al. Aryl hydrocarbon receptor mediates laminar fluid shear stress-induced CYP1A1 activation and cell cycle arrest in vascular endothelial cells. Cardiovasc Res. 2008; 77:809-818. [PubMed: 18065768]

39. Eskin SG, Turner NA, McIntire LV. Endothelial Cell Cytochrome P450 1A1 and 1B1: UpRegulation by Shear Stress. Endothelium. 2004; 11:1-10. [PubMed: 15203874]

40. Lindstedt I, XU CB, Zhang Y, Edvinsson L. Increased perfusion pressure enhances the expression of endothelin (ETB) and angiotensin II (AT1, AT2) receptors in rat mesenteric artery smooth muscle cells. Blood Pressure. 2009; 18:78-85. [PubMed: 19353416]

41. Hankinson $\mathrm{O}$. Role of coactivators in transcriptional activation by the aryl hydrocarbon receptor. Archives of Biochemistry and Biophysics. 2005; 433:379-386. [PubMed: 15581594]

42. Swanson HI, Yang J-H. The Aryl Hydrocarbon Receptor Interacts with Transcription Factor IIB. Molecular Pharmacology. 1998; 54:671-677. [PubMed: 9765510]

43. Yang G, Wu L, Jiang B, Yang W, Qi J, Cao K, et al. H2S as a Physiologic Vasorelaxant: Hypertension in Mice with Deletion of Cystathionine $\hat{I}^{3}$-Lyase. Science. 2008; 322:587-590. [PubMed: 18948540]

44. Fang L, Zhao J, Chen Y, Ma T, Xu G, Tang C, et al. Hydrogen sulfide derived from periadventitial adipose tissue is a vasodilator. Journal of Hypertension. 2009; 27:2174-2185. [PubMed: 19644389] 
45. Fesus G, Dubrovska G, Gorzelniak K, Kluge R, Huang Y, Luft F, et al. \{Adiponectin is a novel humoral vasodilator . Cardiovasc Res. 2007; 75:719-727. [PubMed: 17617391]

46. Şahin AS, Bariskaner H. The mechanisms of vasorelaxant effect of leptin on isolated rabbit aorta. Fundamental \& Clinical Pharmacology. 2007; 21:595-600. [PubMed: 18034660]

47. Yamawaki H, Tsubaki N, Mukohda M, Okada M, Hara Y. Omentin, a novel adipokine, induces vasodilation in rat isolated blood vessels. Biochemical and Biophysical Research Communications. 393:668-672. [PubMed: 20170632]

48. Adams F, Wiedmer P, Gorzelniak K, Engeli S, Klaus S, Boschmann M. Age-Related Changes of Renin-Angiotensin System Genes in White Adipose Tissue of Rats. Horm Metab Res. 2002; 34:716-720. [PubMed: 12660888]

49. Takemori K, Gao Y-J, Ding L, Lu C, Su L-Y, An W-S, et al. Elevated Blood Pressure in Transgenic Lipoatrophic Mice and Altered Vascular Function. Hypertension. 2007; 49:365-372. [PubMed: 17200435]

50. Flaveny CA, Perdew GH. Transgenic Humanized AHR Mouse Reveals Differences between Human and Mouse AHR Ligand Selectivity. Mol Cell Pharmacol. 2009; 1:119-123. [PubMed: 20419055]

51. Poland A, Glover E. 2,3,7,8-Tetrachlorodibenzo-p-dioxin: Segregation of Toxicity with the Ah Locus. Molecular Pharmacology. 1980; 17:86-94. [PubMed: 7383021]

52. Lund AK, Goens MB, Nunez BA, Walker MK. Characterizing the role of endothelin-1 in the progression of cardiac hypertrophy in aryl hydrocarbon receptor (AhR) null mice. Toxicol Appl Pharmacol. 2006; 212:127-135. [PubMed: 16099489] 
A

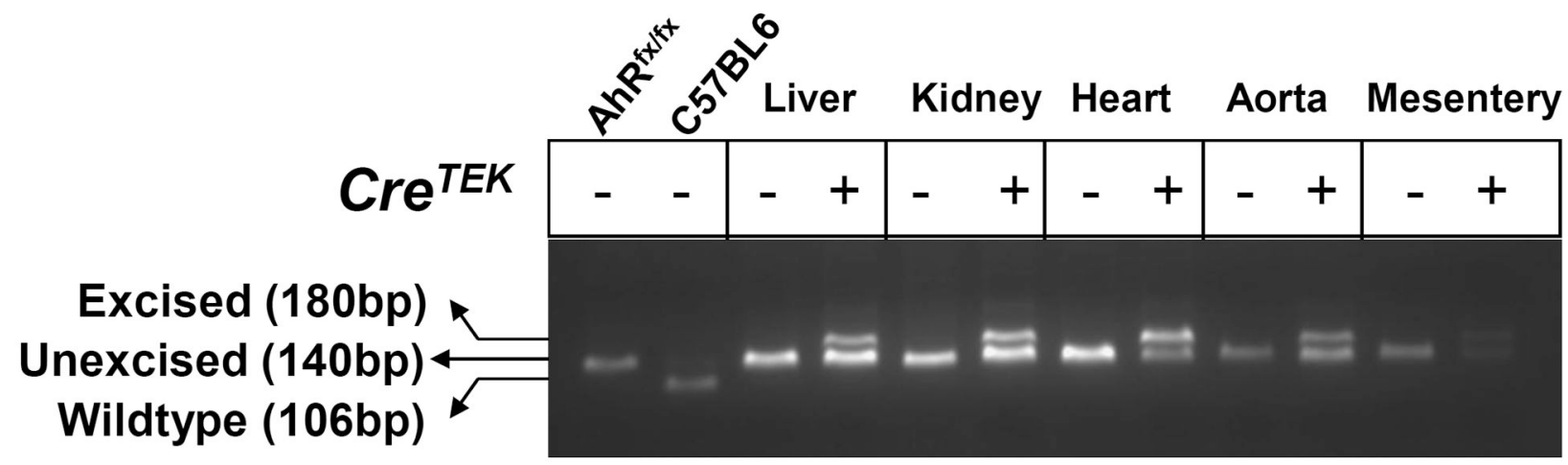

B
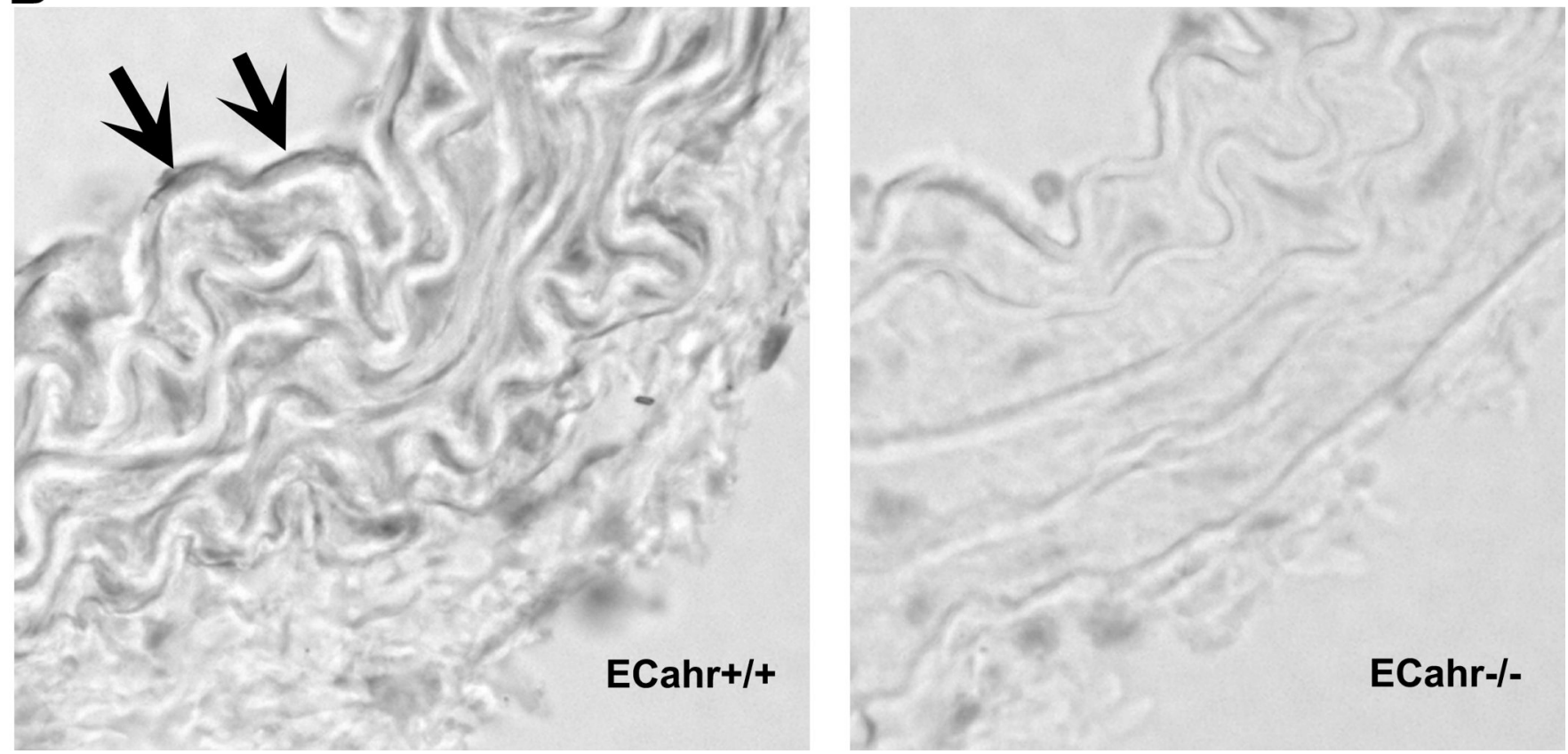

Figure 1.

$\mathrm{Cre}^{\mathrm{Tek}}$-mediated excision of the $a h r$ floxed allele $\left(a h r^{f x} f x\right)$. (A) Excision by $\mathrm{Cre}^{\mathrm{Tek}}$ was determined by genotyping for both the unexcised (140 bp) and excised (180 bp) alleles of $a h r^{f x / f x}$ in genomic DNA isolated from liver, kidney, heart, aorta and mesenteric arterioles obtained from $a h r^{f x / f x} \mathrm{Cre}^{-}\left(\mathrm{EC} a h r^{+/+}\right)$and $a h r^{f x / f x} \mathrm{Cre}^{+}\left(\mathrm{EC} a h r^{-/}\right)$mice. (B) Representative sections of aorta from ECahr ${ }^{-/-}$and ECahr ${ }^{+/+}$mice stained with primary AHR antibody. Positive horseradish peroxidase activity (arrows) can be seen in the endothelium of $\mathrm{EC} a h r^{+/+}$, but absent in the ECahr ${ }^{-l-}$ mice. 


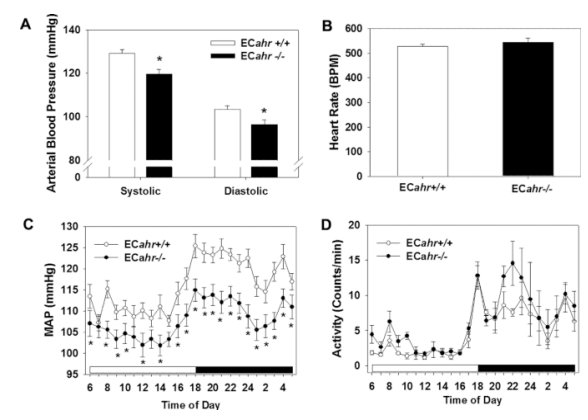

Figure 2.

Loss of $a h r$ alleles in endothelial cells (EC) decreases systolic and diastolic blood pressure. (A) Systolic and diastolic blood pressure, (B) heart rate, (C) hourly mean arterial pressure (MAP) over a $24 \mathrm{hr}$ period (light and dark cycle), and (D) activity of ECahr ${ }^{+/+}$and $\mathrm{ECahr}^{-/-}$mice, as measured by radiotelemetry ( $\mathrm{n}=12 /$ genotype). Data represent mean \pm SEM and were analyzed by Student's t-test; *p $<0.05$, compared to ECahr $r^{+/+}$(A and B) or by two-way, repeated measures ANOVA, using post hoc Holm-Sidak comparisons; *p < 0.05 , compared to $\mathrm{ECahr}^{+/+}$mice (C and D). 
A

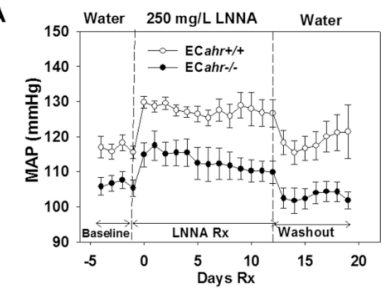

B

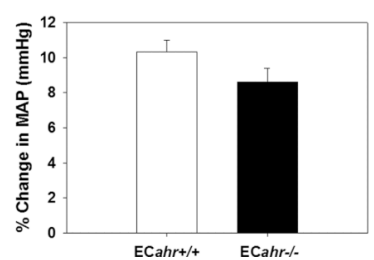

Figure 3.

ECahr ${ }^{-1-}$ mice exhibit normal responses to NOS inhibition by LNNA in vivo. (A) Change in MAP after treatment with $250 \mathrm{mg} / \mathrm{L} \mathrm{LNNA}$ in drinking water of male ECahr ${ }^{-1-}$ and ECahr $r^{+/+}$mice. (B) Percent change in MAP after treatment with $250 \mathrm{mg} / \mathrm{L}$ LNNA. Data represent mean \pm SEM and were analyzed by two-way, repeated measures ANOVA, using post hoc Holm-Sidak comparisons; *p < 0.05, compared to ECahr ${ }^{+/+}(\mathrm{A})$, and by Student's t-test (B) (n=8/genotype for all experiments). 

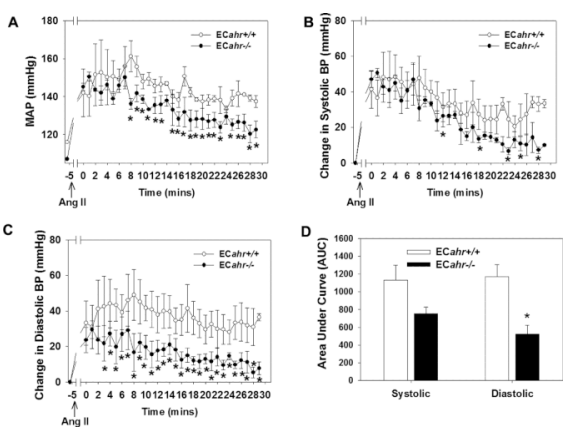

Figure 4.

Loss of $a h r$ in endothelium attenuates RAS responsiveness in vivo. (A) MAP response, (B) change in systolic, $(C)$ change in diastolic blood pressure, and (D) area under curve analysis, for $30 \mathrm{~min}$ following i.p. injection of Ang II $(30 \mu \mathrm{g} / \mathrm{kg})$. Blood pressure was recorded starting after 5 mins of Ang II administration to exclude handling as a confounding factor. Data represent mean \pm SEM and were analyzed by two-way, repeated measures ANOVA, using post hoc Holm-Sidak comparisons; *p < 0.05 compared to $\mathrm{ECahr}^{+/+}$(Fig. A, B, and C). Data in panel (D) were analyzed by student t-test *p $<0.05$ compared to ECahr $r^{+/+}(\mathrm{n}=4 /$ genotype). 

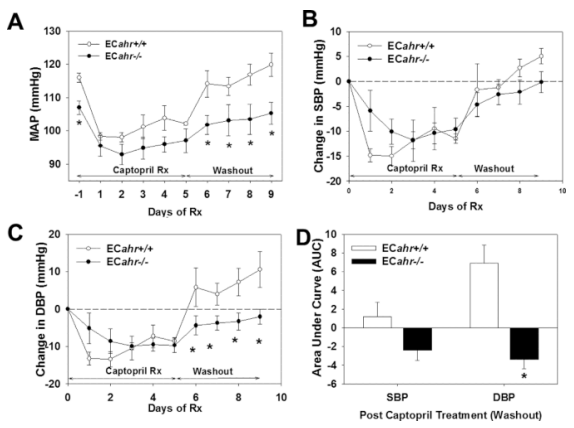

\section{Figure 5.}

Loss of $a h r$ in endothelium attenuates the contribution of Ang II to basal blood pressure. (A) MAP response, (B) change in diastolic, and (C) change in systolic blood pressure, following treatment with $4 \mathrm{mg} / \mathrm{kg}$ ACEi, captopril, in drinking water for $5 \mathrm{~d}$, followed by a $4 \mathrm{~d}$ washout. (D) Area under the curve analysis of systolic and diastolic blood pressure response during washout. Data represent mean \pm SEM and were analyzed by repeated measures twoway ANOVA, using post hoc Holm-Sidak comparisons; *p < 0.05, compared to ECahr ${ }^{+/+}$ (Fig. A, B and C). Data in panel (D) were analyzed by student's t-test *p $<0.05$, compared to $\mathrm{EC} a h r^{+/+}$(n=4/genotype). 
A
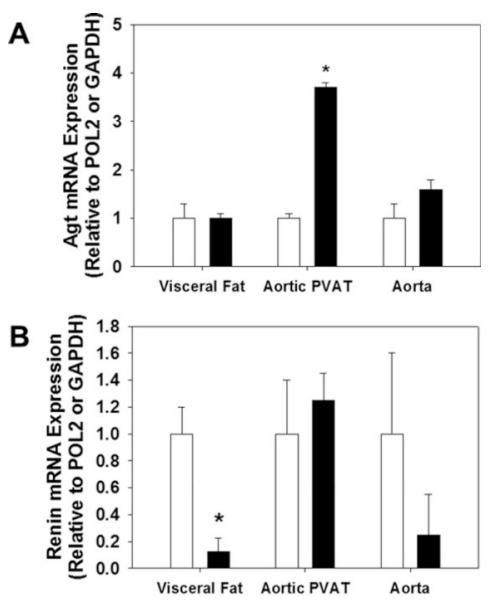

C

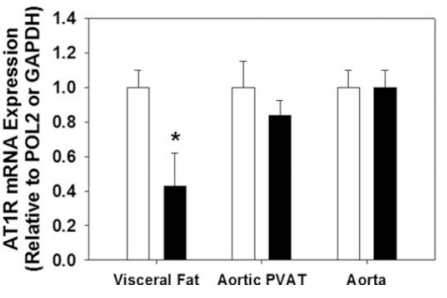

Figure 6.

Loss of $a h r$ in endothelium alters mRNA expression of RAS components in adipose. mRNA quantification of (A) Agt, (B) renin, and (C) AT1R from visceral white adipose, aortic PVAT, and aorta free of PVAT. Data represent mean \pm SEM and were analyzed by Student's t-test; $* P<0.05$, compared to ECahr ${ }^{+/+}$. 
A
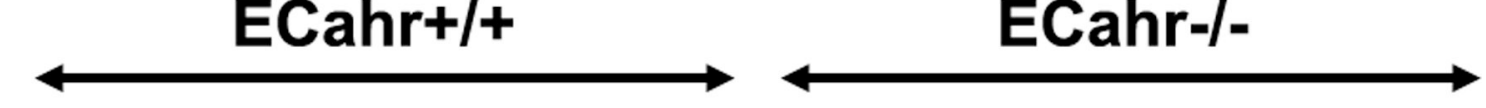

AT1R

GAPDH

B

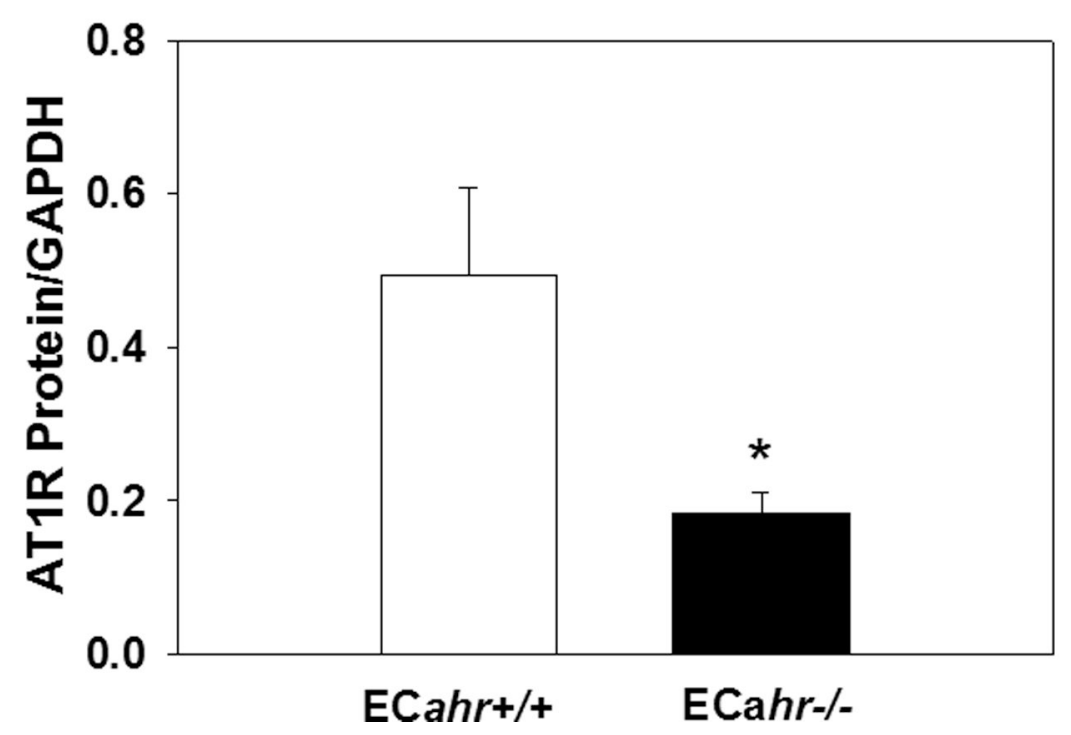

Figure 7.

Loss of $a h r$ in endothelium diminishes AT1R expression in aorta. (A) Representative western blot of abdominal aortic AT1R protein expression. (B) Quantification of AT1R protein expression relative to GAPDH. Data represent mean \pm SEM and were analyzed by Student's t-test; $* P<0.05$, compared to $\mathrm{ECahr}^{+/+}$. 
A

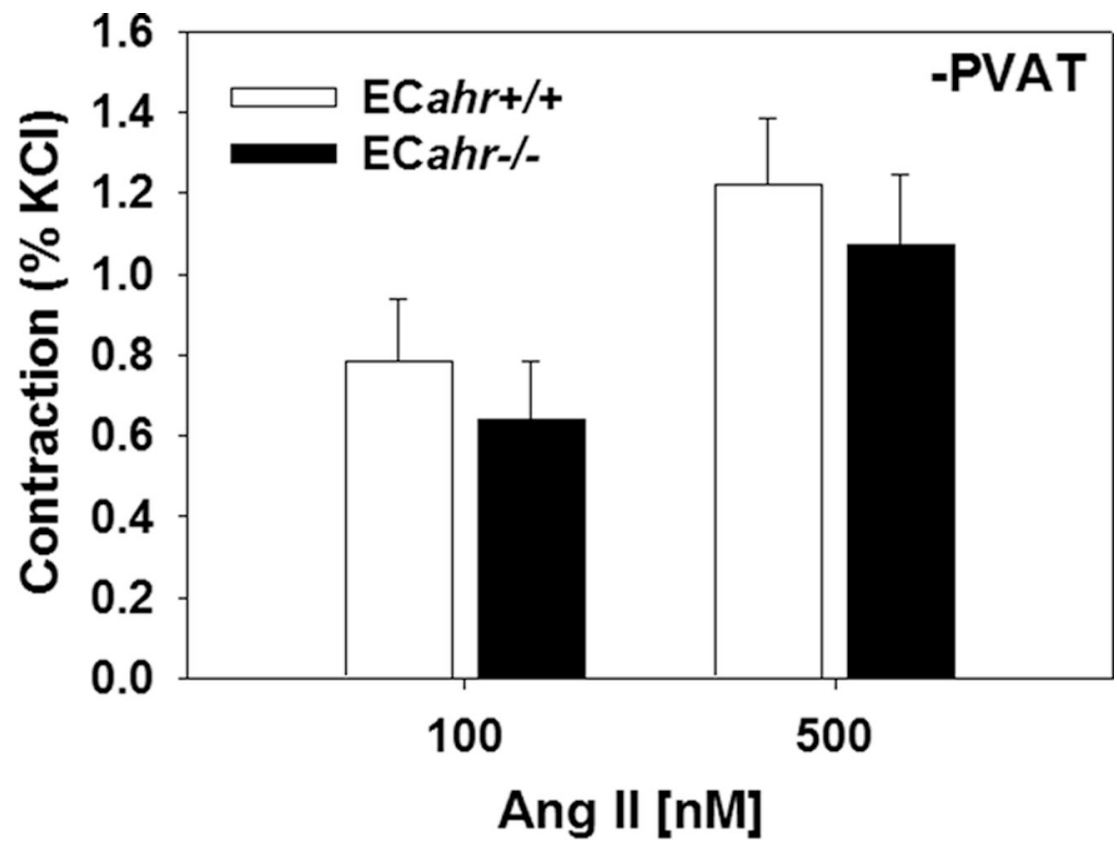

B

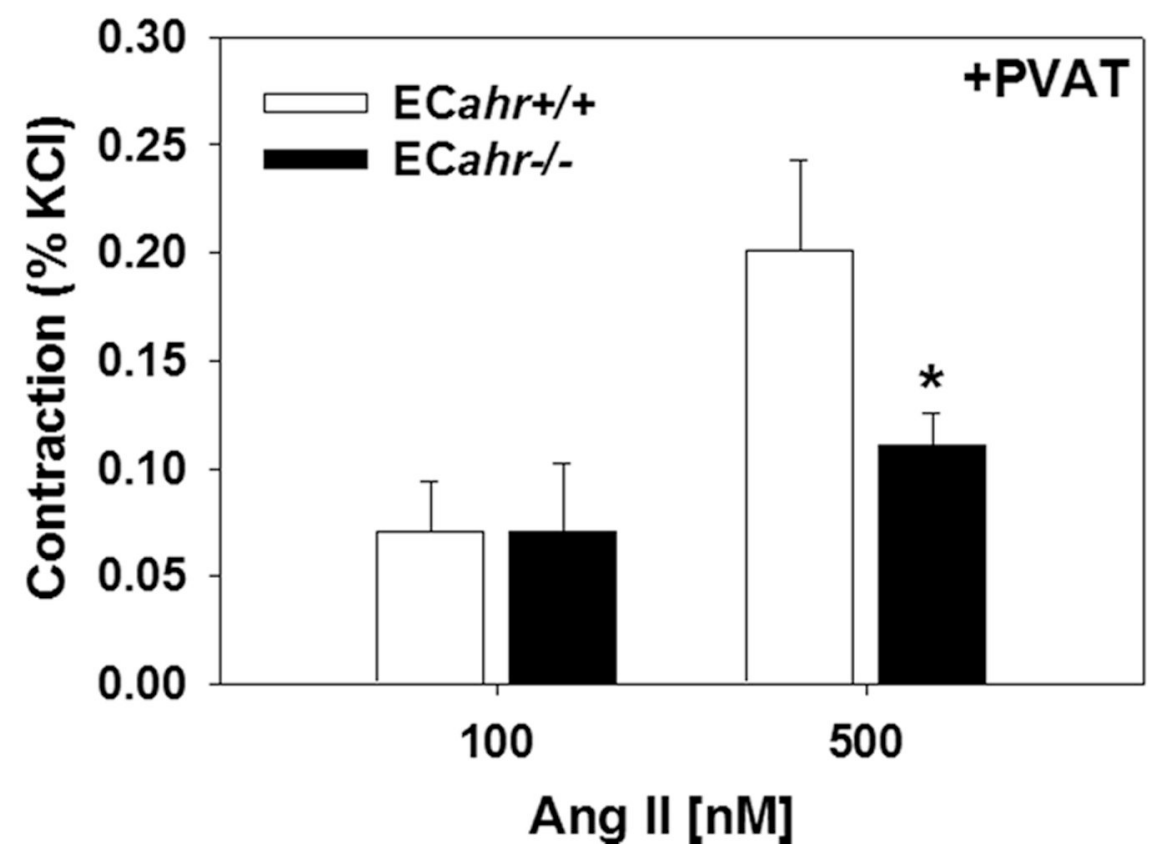

Figure 8.

Loss of $a h r$ in endothelium reduces abdominal aortic reactivity to Ang II in the presence of perivascular adipose tissue (PVAT). (A) Ang II-induced contraction $(\% \mathrm{KCl})$ in absence of PVAT. (B) Ang II-induced contraction (\% KCl) in the presence of PVAT. (ECahr ${ }^{-1-} \mathrm{n}=12$; and $\mathrm{EC} a h r^{+/+} \mathrm{n}=11$ ). Data represent the mean \pm SEM and were analyzed by Student's t-test; $* P<0.05$, compared to ECahr ${ }^{+/+}$. 
Table 1

Body and organ weights of 4-month-old male ECahr $r^{+/+}$and ECahr-l- mice.

\begin{tabular}{|c|c|c|}
\hline Weight & $\begin{array}{c}\mathbf{E C a h h} r^{+/+} \\
(\mathbf{n}=10)\end{array}$ & $\underset{(\mathrm{n}=14)}{\mathbf{E C a h r}}$ \\
\hline Body (g) & $28.8 \pm 0.8$ & $28.7 \pm 0.8$ \\
\hline Heart (mg) & $119 \pm 4(0.412 \pm 0.104)^{\dagger}$ & $130 \pm 4(0.455 \pm 0.137)^{*}$ \\
\hline $\mathrm{LV}+\mathrm{S}(\mathrm{mg})$ & $91.1 \pm 3(0.320 \pm 0.099)$ & $102 \pm 3^{*}(0.358 \pm 0.087)^{*}$ \\
\hline Kidney (mg) & $356 \pm 17(0.616 \pm 0.171)$ & $398 \pm 14(0.694 \pm 0.162)^{*}$ \\
\hline Liver (mg) & $1412 \pm 52(0.049 \pm 0.180)$ & $1110 \pm 57^{*}(0.039 \pm 0.168)^{*}$ \\
\hline
\end{tabular}

Values are expressed as mean \pm SEM

${ }^{*} P<0.05$

${ }^{\dagger}($ Organ/body weight ratio $\times 100)$

Legend: LV+S, Left ventricle + Septum. 
Table 2

Indices of the renin-angiotensin system (RAS) in ECahrt/+ and ECahr-l- mice.

\begin{tabular}{lcc}
\hline Parameter & $\mathbf{E C a h r}^{+/+}(\mathbf{n})$ & $\mathbf{E C a h r ^ { - / }}(\mathbf{n})$ \\
\hline PRA (ng Ang I/ml/hr) & $3.9 \pm 0.2(10)$ & $3.7 \pm 0.2(10)$ \\
Plasma ACE (units/L) & $196 \pm 7(10)$ & $189 \pm 9(10)$ \\
Hematocrit (\%) & $46.8 \pm 0.6(9)$ & $44.9 \pm 1.0(8)$ \\
Plasma Na (mM) & $148.4 \pm 0.8(9)$ & $146.2 \pm 0.9(8)$ \\
Plasma K (mM) & $6.8 \pm 0.2(9)$ & $5.8 \pm 0.2(8)^{*}$ \\
Plasma Cl (mM) & $118.2 \pm 1.2(9)$ & $115.4 \pm 0.9(8)$ \\
Urine Osmolality (mmol/Kg) & $3566.9 \pm 216(9)$ & $3952.1 \pm 260(14)$ \\
\hline
\end{tabular}

Values are expressed as mean \pm SEM

${ }^{*} p<0.05 ; \mathrm{n}$, sample size. 